\title{
TINJAUAN YURIDIS TENTANG HAK ATAS TANAH PERUSAHAAN DI KAWASAN INDUSTRI DI INDONESIA
}

\author{
Ilhamdi \\ Program Pascasarjana Fakultas Hukum Universitas Riau \\ Email: ilham_di92@rocketmail.com
}

\begin{abstract}
Management of industrial areas often face obstacles, such as: setting the industrial area and the implementation of the transfer of land in an industrial area, so that in the process of implementation of the transfer of land in the industrial park needs to be disseminated land use plan with the community or the land owner, the measurement of land area to be released, a detailed mapping of parcels of land to be entered into the industrial area plan, land selling price agreements with landowners, paying the price of land, the people affected by land acquisition or affected have priority to go to work or effort. Moreover, to overcome obstacles in managing the industry, is the need for state intervention as the manifestation of the sovereignty of the state in the economy. Intervention is meant by the author not only through the release of products of the general law, but a special legal product which thoroughly so there is legal certainty and legal synchronization in economic management in industrial areas, like made law on industrial estates.
\end{abstract}

\section{Kata Kunci: Kawasan Industri, Perusahaan Kawasan Industri, Perusahaan Industri dan Hak Atas Tanah}

\section{A. Latar Belakang}

Kawasan Industri adalah kawasan tempat pemusatan kegiatan industri yang dilengkapi dengan sarana dan prasarana penunjang yang dikembangkan dan dikelola oleh Perusahaan Kawasan Industri yang telah memiliki Izin Usaha Kawasan Industri. Dengan demikian investor dapat segera membangun dan mengoperasionalkan pabriknya. Selain itu untuk mendukung kelancaran operasional pabrik tersebut, diperlukan adanya suasana yang kondusif sehingga faktor keamanan, kenyamanan dan ketentraman bagi investor mutlak diperlukan (Pratiknya, 2007: 16).

Berkembangnya suatu Kawasan Industri tidak terlepas dari pemilihan lokasi kawasan industri yang akan dikembangkan, karena sangat dipengaruhi oleh 
beberapa faktor di wilayah lokasi kawasan. Pola Penggunaan Lahan untuk pengembangan kawasan industri adalah Luas areal kapling industri maksimum $70 \%$, Luas ruang terbuka hijau (RTH) minimum 10\%, Jalan dan saluran antara 812\% dan Fasilitas penunjang antara 6-12\% dari total luas areal (Pratiknya, 2014: 27).

Berdasarkan data Kementerian Perindustrian pada 2013 di Indonesia terdapat sebanyak 74 kawasan industri dengan sebaran sebanyak 55 kawasan industri berada di Pulau Jawa dengan total luas 22.796 ha, 16 kawasan industri di Pulau Sumatera dengan luas 4.493 ha, 1 kawasan industri di Pulau Kalimantan seluas 546 ha, dan 2 kawasan industri di Pulau Sulawesi dengan total luas 2.203 ha. Jumlah tersebut akan segera bertambah dengan hadirnya Kawasan Industri baru di 15 lokasi seluas 29.439 ha yang akan dikembangkan (Pratiknya, 2014: 27).

Direktorat Jenderal Pengembangan Perwilayahan Industri, Kementerian Perindustrian memproyeksi kebutuhan lahan kawasan industri antara 2013 hingga 2015 seluas 16.228 ha. Dengan patokan untuk setiap investasi sebesar Rp 1 triliun dibutuhkan lahan kawasan industri seluas 12,5 ha. Angka tersebut mengacu da nilai investasi penanaman modal dalam negeri maupun asing tercatat $\mathrm{Rp} 99,64$ triliun (Pratiknya, 2014: 28).

Dengan asumsi investasi sektor industri kurun 2013-2020 tumbuh 20\% per tahun, kebutuhan lahan kawasan industri di diproyeksikan tahun 2013 seluas 2.373 ha, 2014 seluas 5.220 ha dan 2015 seluas 8.636 ha. Sedangkan sisa lahan kawasan industri sekarang hanya tinggal 7.912 ha. Tanpa penambahan kawasan baru industri atau perluasan kawasan industri yang sudah ada, persediaan lahan kawasan industri di Indonesia habis sejalan peningkatan investasi sektor industry (Pratiknya, 2014: 28).

Perkembangan pembangunan kawasan industri di atas tentunya juga tidak akan lepas dari berbagai macam persoalan. Penyediaan lahan sampai proses pemindahan hak atas tanah di lokasi kawasan industri menjadi permasalahan yang cukup berarti. "Direktur Pengembangan Fasilitas Industri Wilayah 1 Kementerian Perindustrian I Gusti Putu Suryawirawan mengatakan bahwa masalah utama yang 
kerap dihadapi dalam pengembangan kawasan industri adalah lahan (Tanah)" (http://www.antaranews.com).

Tanah dalam wilayah Negara Republik Indonesia merupakan salah satu sumber daya alam utama, yang selain mempunyai nilai batiniah yang mendalam bagi rakyat Indonesia, juga berfungsi sangat strategis dalam memenuhi kebutuhan negara dan rakyat yang makin beragam dan meningkat, baik pada tingkat nasional maupun dalam hubungannya dengan dunia internasional. Pernyataan senada terdapat dalam TAP MPR IX/MPR/2001 (Boedi Harsono 2002: 3).

Tanah dalam Pasal di atas ialah permukaan bumi (Sudarto Gautama 1997: 94).Tanah sebagai benda yang bersifat "permanent" (tidak dapat bertambah) banyak menimbulkan masalah jika dihubungkan dengan pertumbuhan penduduk yang terus meningkat. Perusahaan pada umumnya dianggap berekonomi kuat, sehingga para spekulan dengan uangnya membeli tanah yang luas sekehendaknya untuk mendapat keuntungan yang besar. Sedangkan para pemilik tanah yang kebanyakan rakyat berekonomi lemah, seringkali dipaksa secara langsung atau tidak langsung untuk melepaskan hak atas tanahnya, untuk kemudian suatu perusahaan tertentu menguasai tanah mereka. Spekulasi tanah tersebut banyak menimbulkan keresahan dalam masyarakat (Effendi Perangin 1991: 55).

Untuk menghindari keresahan atau kesulitan di atas, maka peraturan yang pertama kali dikeluarkan oleh pemerintah dalam kaitannya dengan masalah penyediaan tanah dan pemberian tanah untuk keperluan perusahaan adalah Peraturan Menteri Dalam Negeri (Permendagri) No. 5 Tahun 1974. Dikeluarkannya peraturan ini adalah dalam rangka mempermudah perusahaan untuk mendapatkan tanah guna menjalankan usahanya, baik dengan fasilitas penanaman modal dalam negeri, modal asing ataupun yang tidak menggunakan kedua fasilitas tersebut. Sebagai pengganti dari Permendagri No. 5 Tahun 1974 tersebut, Menteri Negara Agraria/Kepala Badan Pertanahan Nasional (BPN) mengeluarkan Permenagria/Kepala BPN No. 2 Tahun 1993 Tentang Tata Cara Memperoleh Izin Lokasi dan Hak Atas Tanah Bagi Perusahaan Dalam Rangka Penanaman Modal (Maya Shofa 2002: 5). 
Begitu banyak arti penting dari keberadaan tanah bagi kehidupan manusia, terutama dalam pembangunan sebuah kawasan industri. Permasalahan status dan proses peralihan hak atas tidak bisa dilakukan semudah membalikkan telapak tangan. Banyak kendalan dan hambatan dalam proses penyediaan lahan tersebut. Mulai dari mencari areal tanah untuk kawasan, proses pemindahan hak milik dari masyarakat, sampai status hak yang dimiliki oleh pengelola perusahaan kawasan industri dan status hak atas tanah yang dimiliki perusahaan industri dikawasan industri.

Lahan yang dibutuhkan oleh perusahaan kawasan industri berdasarkan Pasal 10 PP 24 Tahun 2009 Tentang Kawasan Industri berjumlah minimal 50 hektar dalam satu hamparan, hal ini tentunya sangat sulit dalam penyediaan lahan. Ditambah lagi hak yang diberikan oleh pemerintah terhadap perusahaan kawasan industri dan perusahaan industri berupa Hak Guna Bangunan, yang dalam pelaksanaannya mempunyai sejumlah persyaratan dan batas waktu. Hal ini tentunya telah mengalami penurunan hak, yang dalam prakteknya akan menjadi permasalahan tersendiri. Sehubungan dengan pokok permasalahan yang telah dijelaskan di atas, guna mengetahui apa saja hak-hak keperdataan perusahaanperusahaan di kawasan industri serta kendala yang dihadapi perusahaan di kawasan industri maka penulis tertarik meneliti tentang tentang hak atas tanah perusahaan di kawasan industri.

\section{B. Metode Penelitian}

Jenis penelitian hukum dapat dibedakan menjadi penelitian hukum normatif dan penelitian hukum empiris/sosiologis. Penelitian hukum normatif merupakan penelitian yang datanya bersumber pada data sekunder dan berhubung data penelitian ini adalah data sekunder, maka termasuk dalam jenis penelitian hukum normatif. Sifat penelitian ini adalah deskriptif, yang bertujuan untuk memberikan gambaran tentang gejala-gejala sosial yang terkait dengan hak atas tanah di kawasan industri. Sumber data penelitian berupa bahan hukum primer, bahan hukum sekunder dan bahan hukum tersier. Metode pengumpulan data 
dilakukan menggunakan teknik studi dokumen, yang dianalisis dengan menggunakan teknik analisis kualitatif.

\section{Hasil Penelitian dan Analisis}

\section{Pendekatan teori hukum}

\section{a. Teori tentang kedaulatan}

Kedaulatan merupakan kekuasaan tertingi dalam suatu negara. Ada berbagai macam jenis kedaulatan dalam kajian negara. Istilah-istilah bahasa di atas menunjukan pengertian bahwa kekuasaan tertinggi dalam suatu negara (Concise Routledge 2003: 853), (David Crystal 1990: 1132), (M. Hasbi Amirudin 2000: 101). Dalam Kamus Umum Bahasa Indonesia kedaulatan bermakna kekuasaan yang tertinggi atau hak dipertuan (atas pemerinthan negara) (W.J.S. Poerwadarminta 2005: 169-270).

Adapun macam-macam kedaulatan terdiri atas (https://www.academia.edu/ 10105544/Teori_Kedaulatan_Negara): Kedaulatan Negara di Tangan Rakyat, Kedaulatan Berada di Tangan Hukum, Kedaulatan Berada di Tangan Tuhan, Kedaulatan Berada di Tangan Raja dan Kedaulatan Berada di Tangan Negara.

Pada alinea ke-4 Pembukaan UUD 1945 tersebut, pada baris yang dicetak tebal secara tersurat menunjukkan bahwa negara Indonesia adalah penganut jenis kedaulatan rakyat. Dalam UUD 1945 Pasal 1 ayat 2, ditegaskan bahwa kedaulatan adalah ditangan rakyat dan dilaksanakan menurut Undang-undang Dasar. Berdasarkan uraian tentang kedaulatan rakyat tersebut, jelaslah bahwa negara kita termasuk penganut teori kedaulatan rakyat. Rakyat memiliki kekuasaan yang tertinggi dalam negara, tetapi pelaksanaanya diatur oleh undang-undang dasar. Selain dari penganut jenis kedaulatan rakyat, ternyata UUD Negara RI Tahun 1945, juga menganut jenis kedaulatan hukum. Hal tersebut dapat ditemukan di dalam Pasal 1 ayat 3 UUD 1945, isinya adalah negara Indonesia adalah negara hukum. Artinya negara kita bukan negara kekuasaan (https://www.academia.edu/8864127/Teori_Kedaulatan_Rakyat).

\section{b. Teori intervensi negara}

Ahli yang mengemukakan mengenai pentingnya intervensi pemerintah dalam perekonomian adalah Keynes. Aliran Keynesian yang dipelopori oleh John 
Maynard Keynes muncul untuk mengatasi krisis yang melanda Eropa pada 1930an pasca perang Dunia I. Inti dari ideologi Keynesianisme adalah untuk mengatasi masalah krisis ekonomi, pemerintah harus melakukan lebih banyak campur tangan secara aktif dalam mengendalikan perekonomian nasional. Kegiatan produksi dan pemilikan faktor-faktor produksi masih dapat dipercayakan kepada swasta, tetapi pemerintah wajib melakukan kebijakan-kebijakan untuk mempengaruhi perekonomian (https://www.academia.edu/8864127/Teori_Kedaulatan_Rakyat).

Lahirnya kebijakan pemerintah tentang kawasan industri, merupakan wujud intervensi negara dalam bidang ekonomi. Dengan lahirnya kebijakan ini industri di wajibkan berada dalam satu kawasan yang terintegritas yang disebut dengan kawasan industri.

\section{c. Teori kepastian hukum}

Undang-undang yang berisi aturan-aturan yang bersifat umum menjadi pedoman bagi individu bertingkah laku dalam bermasyarakat, baik dalam hubungan dengan sesama individu maupun dalam hubungannya dengan masyarakat. Aturan-aturan itu menjadi batasan bagi masyarakat dalam membebani atau melakukan tindakan terhadap individu. Adanya aturan itu dan pelaksanaan aturan tersebut menimbulkan kepastian hukum (Peter Mahmud Marzuki 2008: 158).

Menurut Gustav Radbruch, hukum harus mengandung 3 (tiga) nilai identitas, yaitu sebagai berikut (Dwika http://hukum.kompasiana.com):

1) Asas kepastian hukum (rechtmatigheid). Asas ini meninjau dari sudut yuridis.

2) Asas keadilan hukum (gerectigheit). Asas ini meninjau dari sudut filosofis, dimana keadilan adalah kesamaan hak untuk semua orang di depan pengadilan

3) Asas kemanfaatan hukum (zwechmatigheid atau doelmatigheid atau utility.

Tujuan hukum yang mendekati realistis adalah kepastian hukum dan kemanfaatan hukum. Kaum Positivisme lebih menekankan pada kepastian hukum, sedangkan Kaum Fungsionalis mengutamakan kemanfaatan hukum, dan sekiranya dapat dikemukakan bahwa "summum ius, summa injuria, summa lex, summa crux" yang artinya adalah hukum yang keras dapat melukai, kecuali keadilan yang dapat menolongnya, dengan demikian kendatipun keadilan bukan 
merupakan tujuan hukum satu-satunya akan tetapi tujuan hukum yang paling substantif adalah keadilan (Dominikus Rato 2010: 59). Menurut Utrecht, kepastian hukum mengandung dua pengertian, yaitu pertama, adanya aturan yang bersifat umum membuat individu mengetahui perbuatan apa yang boleh atau tidak boleh dilakukan, dan kedua, berupa keamanan hukum bagi individu dari kesewenangan pemerintah karena dengan adanya aturan yang bersifat umum itu individu dapat mengetahui apa saja yang boleh dibebankan atau dilakukan oleh Negara terhadap individu (Riduan Syahrani 1999: 23).

Ajaran kepastian hukum ini berasal dari ajaran Yuridis-Dogmatik yang didasarkan pada aliran pemikiran positivistis di dunia hukum, yang cenderung melihat hukum sebagai sesuatu yang otonom, yang mandiri, karena bagi penganut pemikiran ini, hukum tak lain hanya kumpulan aturan. Bagi penganut aliran ini, tujuan hukum tidak lain dari sekedar menjamin terwujudnya kepastian hukum. Kepastian hukum itu diwujudkan oleh hukum dengan sifatnya yang hanya membuat suatu aturan hukum yang bersifat umum. Sifat umum dari aturan-aturan hukum membuktikan bahwa hukum tidak bertujuan untuk mewujudkan keadilan atau kemanfaatan, melainkan semata-mata untuk kepastian (Achmad Ali 2002: 82-83).

Pada Pasal 33 ayat (1) UUD 1945, dikatakan bahwa "bumi air dan ruang angkasa, termasuk kekayaan alam yang terkandung didalamnya itu pada tingkatan tertinggi dikuasai oleh Negara". Negara sebagai organisasi kekuasaan seluruh rakyat. Hak menguasai dari Negara termaksud dalam UUPA (Pasal 1 ayat 2) memberi wewenang kepada negara untuk:

1) Mengatur dan menyelenggarakan peruntukan, penggunaan, persediaan dan memeliharaan bumi, air dan ruang angkasa tersebut;

2) Menentukan dan mengatur hubungan-hubungan hukum antara orang-orang dengan bumi, air dan ruang angkasa;

3) Menentukan dan mengatur hubungan-hubungan hukum antara orang-orang dan perbuatan-perbuatan hukum yang mengenai bumi, air dan ruang angkasa.

Atas dasar hak menguasai dari Negara sebagai yang dimaksud dalam Pasal

2 ditentukan adanya macam-macam hak atas permukaan bumi, yang disebut 
tanah, yang dapat diberikan kepada dan dipunyai oleh orang-orang baik sendiri maupun bersama-sama dengan orang lain serta badan-badan hukum (UUPA, Pasal 4 ayat 1). Pasal ini memberi wewenang untuk mempergunakan tanah yang bersangkutan demikian pula tubuh bumi dan air serta ruang yang ada diatasnya, sekedar diperlukan untuk kepentingan yang langsung berhubungan dengan penggunaan tanah itu dalam batas-batas menurut undang-undang ini dan peraturan-peraturan hukum lain yang lebih tinggi.

\section{Pengaturan tentang hak atas tanah di kawasan industri}

Tanah dalam wilayah Negara Republik Indonesia merupakan merupakan sumber daya alam utama, selain mempunyai nilai batiniah yang mendalam bagi rakyat indonesia, juga berfungsi sangat strategis dalam memenuhi kebutuhan negara dan rakyat yang makin beragam meningkat, baik pada tingkatan Nasional maupun dalam hubungan Internasional (Boedi Harsono 2002: 3).

Tanah merupakan unsur penting dalam kehidupan karena setiap manusia membutuhkan tanah sebagai tempat tinggal maupun sebagai tempat usaha. Hak milik atas tanah merupakan hak turun-temurun, terkuat dan terpenuh yang dapat dimiliki orang luas dengan mengingat fungsi sosial, dan turun-temurun menunjukan bahwa hak tersebut dapat berlangsung terus selama pemilik masih hidup, dan jika ia meninggal dunia maka hak tersebut dapat dilanjutkan oleh ahli warisnya (Baiq Lisa Mayasari Pratiwi, 2013: 16).

Sebagian pakar menempatkan hukum tanah sebagai bagian dari hukum administrasi Negara dalam sistem hukum nasional. Boedi Harsono menyatakan bahwa di lingkungan administrasi pemerintahan di Indonesia, istilah agararia dipakai dalam arti tanah, baik tanah pertanian maupun nonpertanian. Maka, menurut Boedi Harsono (2003: 5), hukum agraria merupakan bagian dari hukum administrasi Negara.

Hak Negara menguasai bumi berada di sepanjang wilayah kedaulatannya terdiri atas lapisan permukaan bumi dan di bawah permukaan perut bumi. Berdasarkan hak menguasai tersebut dikenal adanya bermacam-macam hak atas permukaan bumi yang disebut tanah, yang dapat diberikan kepada dan dipunyai 
oleh orang-orang, baik sendiri maupun bersama-sama dengan orang-orang lain serta badan-badan hukum (Gatot Supramono 2012: 174).

Hak-hak atas tanah diatur dalam Pasal 16 dan Pasal 54 Undang-Undang Pokok Agraria (UUPA), yaitu hak atas tanah yang bersifat tetap, dan hak atas tanah yang bersifat sementara. Hak atas tanah yang bersifat tetap meliputi hak milik, hak guna usaha, hak guna bangunan, hak pakai, hak sewa, hak membuka tanah,hak memungut hasil hutan dan hak-hak lainnya, sedangkan hak atas tanah yang bersifat sementara adalah hak atas tanah yang sifatnya untuk jangka waktu tertentu dan terbatas dan/atau untuk selama-lamanya, yang meliputi, hak gadai, hak usaha bagi hasil, hak menumpang, hak sewa tanah pertanian (Salim 2013: 89). UUPA juga mengakui hak atas tanah terhadap masyarakat adat yang disebut dengan hak ulayat.

Pengaturan Kawasan Industri di Indonesia secara singkat dapat digambarkan bahwasanya pengaturan mengenai Kawasan Industri yang mana telah diatur dalam Peraturan Menteri Dalam Negeri Nomor 5 tahun 1974, tentang Ketentuan-ketentuan mengenai Penyediaan Tanah untuk Keperluan Perusahaan. Keppres Nomor 53 Tahun 1989, tentang Kawasan Industri. Keppres Nomor 33 Tahun 1990, tentang Penggunaan Tanah bagi Pembangunan Kawasan Industri. Keppres Nomor 53 tahun 1993, tentang Kawasan Industri. Surat Keputuan Menteri Perindustrian Nomor: 230/M/SK/10/ 1993 Tentang, Perubahan SKMenteri Perindustrian Nomor: 291/M/SK/10/ 1989 Tentang Tata Cara Perizinan Dan Standar Teknis Kawasan Industri, Tanggal 23 Oktober 1993. PP Nomor 13 Tahun 1995 tentang Izin Usaha Industri. Keppres Nomor 41 tahun 1996 tentang Kawasan Industri. Serta Undang-Undang Nomor 5 Tahun 1984 Tentang Perindustrian dan Keputusan Presiden Nomor 41 Tahun 1996 Tentang Kawasan Industri. Namun dalam berkembangannya Undang-Undang Nomor 5 Tahun 1984 diganti menjadi Undang-Undang Nomor 3 Tahun 2014 Tentang Perindustrian. Dan diperkuat dengan lahirnya Peraturan Pemerintah (PP) Nomor 24 Tahun 2009 Tentang Kawasan Industri.

Kalau kita lihat dari perkembangan pengaturan hukum dibidang Kawasan Industri. Maka retang waktu keluarnya PP No. 24 Tahun 2009 Tentang Kawasan 
Industri yang mengacu pada Undang-Undang Nomor 5 Tahun 1984 Tentang Perindustrian adalah +25 tahun, Sungguh rentan waktu yang sangat lama. Keluarnya PP tersebut, juga kurang lengkap menjelaskan apa yang diamanatkan oleh Undang-Undang Nomor 5 Tahun 1984 Tentang Perindustrian.

Selain itu Undang-Undang Nomor 5 Tahun 1984 Tentang Perindustrian juga telah diperbaharui dengan Undang-Undang Nomor 3 Tahun 2014 Tentang Perindustrian. Sudah berjalan sekitar 2 tahun lebih Peraturan Pemerintah yang mengacu terhadap Undang-Undang Nomor 3 Tahun 2014 ini juga belum dikeluarkan pemerintah.

Permasalahan di atas tentunya sangat berpengaruh kepada kepastian hukum dalam hal pengaturan tentang Kawasan Industri. Padahal dalam suatu bisnis kepastian hukum tentunya faktor yang sangat dibutuhkan dalam menarik minat investor dalam menanamkan modalnya di Indonesia.

Perusahaan Kawasan Industri dan Perusahaan Industri tentunya masih ragu dalam menjalankan aktivitasnya akibat pengaturan hukum tentang Kawasan Industri yang cenderung tidak konsisten. Pemerintah juga dinilai kurang tanggap dengan perkembangan Kawasan Industri ini, hal ini dibuktikan dengan fase-fase keluarnya pengaturan tentang Kawasan Industri yang menggambarkan ketidakpastian.

Kebijakan publik merupakan kewenangan pemerintah menjalankan tugas dan fungsinya dalam hubungannya dengan masyarakat dan dunia usaha. Pada dasarnya kebijakan pemerintah dalam mengembangkan kawasan industri merupakan kebijakan negara yang berorientasi pada kepentingan publik (masyarakat). Pengertian kebijakan (policy) adalah prinsip atau cara bertindak yang dipilih untuk mengarahkan pengambilan keputusan (Suharto 2005: 7).

M. Irfan Islamy (1997: 20) menguraikan beberapa elemen penting dalam kebijakan publik, yaitu:

a. Bahwa kebijakan publik itu dalam bentuk peraturannya berupa tindakantindakan pemerintah.

b. Bahwa kebijakan publik itu tidak cukup hanya dinyatakan sebagai wacana, tetapi dilaksanakan dalam bentuk yang nyata. 
c. Bahwa kebijakan publik baik untuk melakukan sesuatu ataupun tidak melakukan sesuatu itu mempunyai dan dilandasi maksud dan tujuan tertentu.

\section{Pelaksanaan pemindahan hak atas tanah di kawasan industri}

Kepemilikan tanah sebagai hak-hak individual yang bersifat pribadi kemudian telah disatukan dalam hak bangsa selanjutnya negara dimungkinkan memberikan kembali kepada individu yang ikut mempunyai hak bersama tersebut untuk menguasai dan mempergunakan sebagai hak pribadi. Kemudian hak pribadi tersebut menunjukkan kepada pemegang hak untuk menggunakan tanah yang bersangkutan bagi dirinya dan keluarganya sebagaimana ditegaskan dalam Pasal 9 UUPA. Penggunaan tanah tersebut harus disesuaikan dengan keadaannya dan sifat dari haknya. Dengan demikian pula penggunaan tanah untuk kawasan industri juga betul-betul sesuai dengan keadaan dan sifat dari haknya, sehingga memberikan manfaat baik bagi kesejahteraan dalam usaha pemenuhan kebutuhan tempat tinggal dan kebahagiaan yang mempunyainya, maupun bermanfaat pula bagi masyarakat dan negara.

Namun, demikian terdapat permasalah ketika pemerintah menetapkan suatu kawasan menjadi suatu kawasan industri. Sementara letak kawasan tersebut merupakan tanah hak milik masyarakat. Dengan demikian maka masyarakat yang mempunyai tanah tersebut terpaksa melepaskan haknya tersebut, dari status hak milik menjadi hak guna bangunan yg dikelola oleh perusahaan kawasan industri. Penetapan kawasan industri tersebut merupakan sebagai bentuk intervensi negara sebagai pemegang kedaulatan.

Sedangkan kedaulatan ekonomi negara adalah kekuatan tertinggi suatu negara untuk mengatur di dalam wilayahnya kebijakan ekonomi internasional, sedangkan pengertian kedaulatan ekonomi negara menurut Kuresi adalah keseluruhan kekuasaan ekonomi negara, termasuk persamaan status dalam hubungan-hubungan ekonomi internasional. Kekuasaan ekonomi negara lebih banyak berkenaan dengan kekuasaan negara terhadap kepercayaan alamnya, sistem ekonominya dan aturan-aturan perjanjian dalam hubungan-hubungan ekonomi internasional, sedangkan persamaan status disini berkaitan erat dengan persamaan dengan kemerdekaan negara termasuk dalam hak dan kewajiban. 
Pengembangan Kawasan Industri sebagaimana tercantum dalam Peraturan Pemerintah Nomor 24 Tahun 2009 tentang Kawasan Industri, bertujuan untuk mengendalikan pemanfaatan ruang, meningkatkan upaya pembangunan industri yang berwawasan lingkungan, mempercepat mempercepat pertumbuhan industri di daerah, meningkatkan daya saing industri, meningkatkan daya saing investasi, memberikan jaminan kepastian lokasi dalam perencanaan dan pembangunan infrastruktur, yang terkoordinasi antar sektor terkait.

Dari beberapa point di atas, maka point (f) sangat berkaitan erat dengan kepastian hak atas tanah yang diperoleh oleh Perusahaan Kawasan Industri. Sebelum Perusahaan Kawasan Industri memilih lokasi kawasan Industri maka Perusahaan Kawasan Industri harus mempertimbangkan kriteria pemilihan lokasi sesuai yang diamanatkan Peraturan Menteri Perindustrian Republik Indonesia Nomor: 35/M-IND/PER/3/2010 Tentang Pedoman Teknis Kawasan Industri.

Peraturan Menteri Perindustrian Republik Indonesia Nomor: 35/MIND/PER/3/2010 Tentang Pedoman Teknis Kawasan Industri menentukan Pembangunan Kawasan Industri dapat dilakukan apabila sebelumnya telah dilakukan studi pra kelayakan, studi AMDAL, dan penyusunan Master Plan. Yang dimaksud dengan pembangunan kawasan industri adalah pelaksanaan konstruksi atau membangun kawasan industri secara fisik.

Peraturan Menteri Perindustrian Republik Indonesia Nomor: 35/MIND/PER/3/2010 Tentang Pedoman Teknis Kawasan Industri juga menegaskan untuk proses pembebasan lahan maka Perusahaan Kawasan Industri perlu dipertimbangkan adalah:

a. Melakukan sosialisasi rencana peruntukan lahan dengan masyarakat atau pemilik lahan;

b. melakukan pengukuran luas lahan yang akan dibebaskan, melakukan pemetaan secara detail persil luas lahan yang akan masuk ke dalam rencana kawasan industry;

c. membuat kesepakatan harga jual lahan dengan pemilik lahan;

d. membayar harga lahan, masyarakat yang terkena pembebasan lahan atau yang terkena dampak mendapat prioritas untuk ikut bekerja atau berusaha. 
Berdasarkan penjelasan di atas maka dapat gambarkan bahwa Perusahaan Kawasan Industri awalnya harus melakukan sosialisasi kepada pemilik lahan. Pemilik lahan dalam hal ini bisa saja tanah yang dimiliki oleh masyarakat maupun tanah yang dimiliki oleh negara. Setalah dilakukan pembebasan tersebut, maka diberikanlah Hak Guna Bangunan atas tanah tersebut oleh pemerintah kepada Perusahaan Kawasan Industri di luar BUMN dan BUMD. Jika Perusahaan Kawasan Industri tersebut BUMN dan BUMD maka diberikan Hak Pengelolaan, di atas Hak Pengelolaan tersebut dapat diberikan Hak Guna Bangunan berdasarkan usul pemegang Hak Pengelolaan.

Setelah itu Perusahaan Kawasan Industri mengkaveling-kaveling tanah sesuai kebutuhan untuk di jual atau disewa oleh Perusahaan Industri. Jadi, permohonan Hak Guna Bangunan (HGB) dilakukan dalam 2 (dua) tahap. Tahap pertama dilakukan permohonan HGB Induk untuk keseluruhan Kawasan Industri. Tahap berikutnya diajukan permohonan HGB untuk masing-masing kaveling industri.

Status tanah yang diberikan pemerintah kepada Perusahaan Kawasan Industri berupa HGB sebenarnya telah menurunkan status hak atas tanah dari Hak Milik ke Hak Guna Bangunan. Jika kita kaitkan dengan Pasal 37 UUPA menegaskan bahwa Hak Guna Bangunan terjadi pada tanah yang dikuasai langsung oleh Negara atau tanah milik orang lain. Sedangkan Pasal 21 PP No. 40 Tahun 1996 menegaskan bahwa tanah yang dapat diberikan dengan Hak Guna Bangunan adalah tanah negara, tanah Hak Pengelolaan, atau tanah Hak Milik. Maka menurut penulis pemecahan HGB yang diberikan kepada perusahaan industri juga akan multitafsir, apakah nanti perusahaan industri dapat menggabungkan sertifikat HGB yang mereka miliki. Karena bagaimanapun bisa saja perusahaan industri dengan berbagai faktor ingin menggabungkan lokasi industri untuk kemajuan bisnis mereka sehingga memperoleh keuntungan yang besar.

\section{Solusi dalam mengatasi hambatan dalam pengelolaan kawasan industri}

Jika dilihat bagaimana pengaturan dan proses pemindahan hak atas tanah yang digunaan dalam peruntukan Kawasan Industri pada rumusan masalah A dan 
B, maka terdapat berbagai macam hambatan dalam pengembangan Kawasan Industri, seperti: Jarak keluarnya PP No. 24 Tahun 2009 Tentang Kawasan Industri yang mengacu pada Undang-Undang Nomor 5 Tahun 1984 Tentang Perindustrian adalah +25 tahun, Sungguh rentan waktu yang sangat lama. Keluarnya PP tersebut, juga kurang lengkap menjelaskan apa yang diamanatkan oleh Undang-Undang Nomor 5 Tahun 1984 Tentang Perindustrian.

Undang-Undang Nomor 5 Tahun 1984 Tentang Perindustrian juga telah diperbaharui dengan Undang-Undang Nomor 3 Tahun 2014 Tentang Perindustrian. Sudah berjalan sekitar 2 tahun lebih Peraturan Pemerintah yang mengacu terhadap Undang-Undang Nomor 3 Tahun 2014 ini juga belum dikeluarkan pemerintah. Sehingga berdampak pada kurangnya kepastian hukum dari pengaturan tentang Kawasan Industri.

HGB hanya bisa diperoleh dari tanah negara, tanah hak pengelolaan atau tanah hak milik bukannya tanah atas HGB induk, hal ini akan menimbulkan multitafsir, sehingga bisa saja perusahaan industri melakukan pemecahan sertifikat HGB atau penggabungan HGB secara sendiri-sendiri.

Sulitnya melaksanakan pembebasan lahan antara masyarakat dan Perusahaan Kawasan Industri ataupun antara Pemerintah dengan Perusahaan Kawasan Industri, dikarena terkadang ada masyarakat yang sama sekali tidak mau menjual tanahnya atau nilai ganti rugi atas tanah tersebut tidak sesuai dengan kehendak masyarakat atau karena pemerintah tidak memberi izin atas tanah tersebut menyangkut kepentingan dari berbagai instansi pemerintah tersebut.

Terjadinya lempar tanggung jawab antara Pemerintah dengan Perusahaan Kawasan Industri atau Perusahaan Kawasan Industri dengan Perusahaan Industri (investor) mengenai sarana dan prasarana serta hak dan kewajiban dari masingmasing pihak. Mengingat hal ini tidak diatur secara lengkap dalam UndangUndang Nomor 5 Tahun 1984 jo Undang-Undang Nomor 3 Tahun 2014, Peraturan Pemerintah Nomor 24 Tahun 2009 Tentang Kawasan Industri dan Peraturan Menteri Perindustrian Nomor: 35/M-IND/PER/3/2010 Tentang Pedoman Teknis Kawasan Industri. 
Untuk menyelesaikan berbagai persoalan di atas, maka perlu adanya intervensi negara sebagai wujud kedaulatan negara dalam bidang ekonomi. Intervensi yang dimaksud oleh penulis bukan hanya melalui keluarnya produkproduk hukum yang bersifat umum, melainkan suatu produk hukum khusus dan menyeluruh sehingga ada kepastian hukum dan sinkronisasi hukum dalam pengelolaan ekonomi berdasarkan pancasila dan UUD 1945. Negara jangan berpedoman pada kebijakan-kebijakan ekonomi di negara lain, sehingga produk hukumnyapun meniru produk hukum negara lain.

Negara harus menjamin atas pelaksanaan dari keluarnya produk hukum yang keluar dengan membentuk Panitia atau team pengawas independen membidangi Pengelolaan Kawasan Industri, negara juga harus konsisten antara tujuan dengan produk hukum yang keluar, negara juga harus mengatur secara lengkap tentang kegiatan-kegiatan yang berhubungan dengan kawasan industri sehingga tidak ada lagi peraturan yang keluar dengan beberapa pasal saja, yang tidak mengatur secara menyeluruh, negara juga harus memberikan kepastian hukum para investor dalam berbisnis di kawasan industri serta banyak lagi bentuk intervensi negara sehingga memberikan kepastian hukum bagi para pemangku kepentingan di kawasan industri.

\section{Simpulan dan Saran}

\section{Simpulan}

Berdasarkan hasil pembahasan sebelumnya, maka diperoleh simpulan adalah perusahaan Kawasan Industri dan Perusahaan Industri tentunya masih ragu dalam menjalankan aktivitasnya akibat pengaturan hukum tentang Kawasan Industri yang cenderung tidak konsisten. Pemerintah juga dinilai kurang tanggap dengan perkembangan Kawasan Industri ini, hal ini dibuktikan dengan fase-fase keluarnya pengaturan tentang Kawasan Industri yang menggambarkan ketidakpastian serta isi dari setiap pengaturan yang dinilai masih kurang lengkap.

Proses Pelaksanaan pemindahan hak atas tanah di Kawasan Industri melakukan sosialisasi rencana peruntukan lahan dengan masyarakat atau pemilik lahan, melakukan pengukuran luas lahan yang akan dibebaskan, melakukan 
pemetaan secara detail persil luas lahan yang akan masuk ke dalam rencana kawasan industri, membuat kesepakatan harga jual lahan dengan pemilik lahan, membayar harga lahan, masyarakat yang terkena pembebasan lahan atau yang terkena dampak mendapat prioritas untuk ikut bekerja atau berusaha.

Proses pelaksanaan pemindahan hak atas tanah ini sangat sulit dilaksanakan karena pemilik lahan yang tidak mau melepaskan hak miliknya, kriteria lokasi yang tidak sesuai serta pengaturan mengenai hak dan kewajiban sebagai pemangku kepentingan yang tidak diatur secara jelas. Dengan berbagai kendala di atas maka investor kurang tertarik untuk berinvestasi di Kawasan Industri.

Solusi Dalam Mengatasi Hambatan Dalam Pengelolaan Kawasan Industri. Maka perlu adanya intervensi negara sebagai wujud kedaulatan negara dalam bidang ekonomi. Intervensi yang dimaksud oleh penulis bukan hanya melalui keluarnya produk-produk hukum umum, melainkan suatu produk hukum khusus yang menyeluruh sehingga ada kepastian hukum dan sinkronisasi hukum dalam pengelolaan ekonomi dalam kawasan industri.

\section{Saran}

Berdasarkan uraian di atas, maka pengaturan mengenai Kawasan Industri harus dibuat lebih lengkap dan jelas sehingga tidak menimbulkan multi tafsir. Peraturan satu dan yang lainnya haruslah sinkron sehingga dapat memberikan rasa kepastian hukum. Jadi, produk hukum yang dikeluarkan pemerintah bisa mencakup semua aspek mengenai Kawasan Industri.

Pelaksanaan pemindahan hak atas tanah di Kawasan Industri jangan diserahkan sepenuhnya pada Perusahaan Kawasan Industri. Pemerintah juga mempunyai peran strategis dalam proses pelaksanaan pemindahan hak atas tanah tersebut, seperti penetapan harga, memberikan kemudahan memperoleh status hak atas tanah, meyakinkan pemilik lahan, dan memberikan kepastian kepada masyarakat tempatan akan manfaat dari berdirinya kawasan industri.

Pemerintah tidak boleh merasa aman dengan telah mengeluarkan berbagai kebijakan di Kawasan Industri. Pemerintah bisa saja mengintervensi Perusahaan Kawasan Industri dan Perusahaan Industri apabila sudah merugikan negara atau 
masyarakat. Apalagi konsep bisnis hanya mencari keuntungan saja, tanpa memikirkan dampak lingkungan maupun sosial kemasyarakatan. Untuk itu perlu peran pemerintah dalam memberikan kebijakan dalam pengelolaan dan pemanfaatan kawasan industri yang khusus dan menyeluruh, seperti: dibuatnya Undang-Undang tentang kawasan industri. 


\section{DAFTAR PUSTAKA}

\section{Buku:}

Achmad Ali. 2002. Menguak Tabir Hukum (Suatu Kajian Filosofis dan Sosiologis), Jakarta: Penerbit Toko Gunung Agung.

Amirudin Hasbi, M. 2000. Konsep Negara Islam menurut Fazlur Rahman, Yogyakarta: UII Press.

Boedi Harsono. 2002. Menuju Penyempurnaan Hukum Tanah Nasional dalam hubungannya dengan TAP MPR RI IX/MPR/2001, Jakarta: Universitas Trisakti.

---------. 2003. Hukum Agraria Indonesia, Sejarah Pembentukan Undangundang Pokok Agraria, Isi dan Pelaksanaannya, Jilid I, Hukum Tanah Nasional, Jakarta: Djambatan.

Crystal David (ed). 1990. The Cambridge Encylopedia, Australia: Cambridge University Press.

Edi Suharto. 2005. Analisis Kebijakan Publik, Panduan Praktis mengkaji Masalah dan Kebijakan Sosial, Bandung: Alfabeta.

Gatot Supramono. 2012. Hukum Pertambangan Mineral dan Batu Bara di Indonesia, Jakarta: PT Rineka Cipta.

Irfan Islamy, M. 1997. Prinsip-prinsip Perumusan Kebijaksanaan Negara, Jakarta: Bumi Aksara.

Perangin, Effendi. 1991. Praktek Permohonan Hak Atas Tanah, Jakarta: Rajawali Press.

Poerwadarminta, S.J.W. 2005. Kamus Umum Bahasa Indonesia, Jakarta: Balai Pustaka.

Pratiknya. 2003. Concise Routledge Encylopedia of Philosopy Routledge: New York.

--------. 2014. Penawaran Daftar Peraturan Kawasan Di Indonesia, Jakarta: PT. Media Data Riset.

Rato Dominikus. 2010. Filsafat Hukum Mencari: Memahami dan Memahami Hukum, Yogyakarta: Laksbang Pressindo.

Riduan Syahrani. 1999. Rangkuman Intisari Ilmu Hukum, Bandung: Citra Aditya Bakti.

Salim H.S. 2013. Hukum Penyelesaian Sengketa Pertambangan di Indonesia, Bandung: Pustaka Reka Cipta. 
Sudarto Gautama. 1997. Tafsiran Undang-Undang Pokok-Pokok Agraria (1960) dan Peraturan-peraturan Pelaksanaannya (1996), Cetakan Kesepuluh, Bandung: Citra Aditya Bakti.

\section{Tesis dan Jurnal:}

Baiq Lisa Mayasari Pratiwi. 2013. "Penguasaan Hak Atas Tanah yang Belum Dibagi Waris Ditinjau dari Perspektif Hukum Agraria Nasional”, Jurnal Ilmiah, Fakultas Hukum Universitas Mataram.

Pratiknya. 2007. "Pengembangan Kawasan Industri Dalam Meningkatkan Investasi”, Tesis, Bandung: UNDIP

Satrowardoyo Sanyoto. 1989. "Pengembangan Kawasan Industri Dalam Rangka Menarik Penanam Modal", Makalah, disampaikan pada rapat kerja Himpunan Kawasan Industri, Surabaya.

Shofa Maya. 2002. "Pelaksanaan Pemberian Hak Atas Tanah bagi Perusahaan di Kawasan Industri Terboyo Kota Semarang", Tesis, Semarang

\section{Peraturan Perundang-Undangan:}

Republik Indonesia, Undang-Undang Nomor 5 Tahun 1960, tentang Peraturan Dasar Pokok-Pokok Agraria.

Republik Indonesia, Peraturan Pemerintah Nomor 24 Tahun 2009, tentang Kawasan Industri.

Republik Indonesia, Peraturan Menteri Perindustrian Nomor: 35/M-IND/PER/3/ 2010, tentang Pedoman Teknis Kawasan Industri.

\section{Imternet:}

https://www.academia.edu/10105544/Teori_Kedaulatan_Negara, diakses pada 29 Maret 2016.

http://hukum.kompasiana.com. diakses pada Tanggal 29 Maret 2016.

https://www.academia.edu/8864127/Teori_Kedaulatan_Rakyat, diakses pada tanggal 15 Mei 2016.

http://www.antaranews.com/berita/489834/lahan-jadi-masalah-pengembangankawasan-industri, diakses pada Tanggal 19 Desember 2015. 


\section{BIODATA PENULIS}

$\begin{array}{ll}\text { Nama } & : \text { Ilhamdi } \\ \text { Pekerjaan } & : \text { Mahasiswa Program Pascasarjana Fakultas Hukum Universitas } \\ & \text { Riau } \\ \text { Jabatan } & :- \\ \text { Nomor HP } & : 082381607393 \\ \text { E-mail } & : \text { ilham_di92@ @rocketmail.com } \\ \text { Alamat Kantor } & : \text { Kampus Bina Widya Km 12.5, Simpang Baru Pekanbaru- } \\ & 28293\end{array}$

